\title{
Retrospective Analysis of the first 100 Kidney Transplants at the Istanbul Okan University, Health Application and Research Center
}

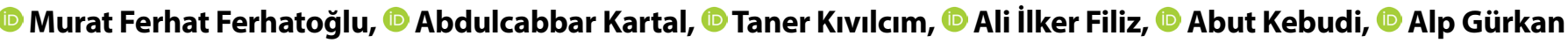 \\ Department of General Surgery, Istanbul Okan University, Faculty of Medicine, Istanbul, Turkey
}

\begin{abstract}
Objectives: The renal transplant program of Istanbul Okan University Hospital started in August 2017. Five cadaveric and 95 living donor kidney transplants have been performed for over 16 months. In this study, we aimed to share our experiences regarding kidney transplantation.

Methods: In this study, a retrospective analysis of 100 patients who underwent kidney transplantation at the Istanbul Okan University over 16 months, the Health Application and Research Center was carried out. Patients' demographics, creatinine levels of donors and recipients, co-morbid conditions, postoperative complications, features of arterial anastomosis and arterial variations observed on computed tomography angiography of donor-patient were assessed.

Results: Mean age of donor patients was $44.05 \pm 13.76$ (18-71) years. All living donors had computed tomography angiography for assessment of the vascular structure of both kidneys. Accessory right kidney artery was the most dominant vascular variation (16.5\%). The primary cause of chronic renal disease was diabetes mellitus (36.4\%) and hypertension (15.6\%). Mean warm and cold ischemia time was $1.82 \pm 0.44$ (1-3) and 40.25 \pm 6.12 (31-57) minutes, respectively. The most observed postoperative complication was stenosis of ureter anastomosis (4.1\%). End-to-end arterial anastomosis between renal and internal iliac arteries was the most preferred anastomosis (57.2\%).

Conclusion: Increasing kidney transplantation, which is the most appropriate treatment in terms of cost-effectiveness, will be beneficial for patient health and economy of the country.

Keywords: Cadaver; donation; donor; Istanbul; kidney; nephrectomy; transplantation.

Please cite this article as "Ferhatoğlu MF, Kartal A, Kıvılcım T, Filiz Al, Kebudi A, Gürkan A. Retrospective Analysis of the first 100 Kidney Transplants at the Istanbul Okan University, Health Application and Research Center. Med Bull Sisli Etfal Hosp 2019;53(3):221-227".
\end{abstract}

$\mathrm{E}_{\mathrm{t} \text { sis }}$ nd-stage kidney disease is a worldwide health problem that can be defined as a burden, with a prevalence rate of $11-13 \% .{ }^{[1]}$ Definitive treatment of end-stage kidney disease is kidney transplantation, which provides better clinical outcomes, including overall survival compared to longterm dialysis treatment. ${ }^{[2,3]} \mathrm{A}$ one-year graft survival rate of the transplanted kidney is increased to over $90 \%$ by the advances in tissue sampling and immunosuppression. ${ }^{[4]}$

In 2016, 89.823 kidney transplant surgeries were performed worldwide. $40.2 \%$ of these transplants were from living donors and $59.8 \%$ were from deceased donors. ${ }^{[5]}$ Clinical results of living donor kidney transplantation are two times better than deceased donor kidney transplantation. ${ }^{[1]}$ Paired kidney exchange transplantation is an al-

Address for correspondence: Murat Ferhat Ferhatoğlu, MD. Istanbul Okan Universitesi Tip Fakultesi, Genel Cerrahi Anabilim Dali, Istanbul, Turkey Phone: +90 5553214793 E-mail: ferhatferhatoglu@gmail.com

Submitted Date: March 09, 2019 Accepted Date: April 05, 2019 Available Online Date: August 21, 2019

${ }^{\circ}$ Copyright 2019 by The Medical Bulletin of Sisli Etfal Hospital - Available online at www.sislietfaltip.org

OPEN ACCESS This is an open access article under the CC BY-NC license (http://creativecommons.org/licenses/by-nc/4.0/) 
ternative solution for the end-stage renal disease, which might be more preferred in countries having low rates of deceased organ donation and increases the rate of living donor transplants. ${ }^{[6]}$

The renal transplant program of Istanbul Okan University, Health Application and Research Center started in August 2017. Five cadaveric, 95 living donor kidney transplants have been performed over 16 months. The kidney transplant team includes five surgeons, ${ }^{[5]}$ five anesthesiologists, ${ }^{[5]}$ a nephrologist, a psychiatrist, a cardiologist, an urologic surgeon, a radiologist, an infectious disease specialist, an organ donation coordinator, and two transplant nurses, ten nurses (one donor patient coordinator, one clinical nurse coordinator nurse). During the 16 months, ninetyfive living donors and five cadaveric kidney transplants. The donor was relatives in 71 cases (thirteen crossovers, eleven non-relative kidney transplants with an ethical committee approval).

In this study, we aimed to share our experiences regarding kidney transplantation.

\section{Methods}

A retrospective analysis of 100 patients who underwent kidney transplantation between August 2017 and January 2019 at the Istanbul Okan University, Health Application and Research Centerwas performed. Patient data were obtained from patient files, service follow-up charts, and outpatient follow-up charts. Patients' demographics, creatinine levels of donors and recipients, co-morbid conditions, postoperative complications, features of arterial anastomosis and arterial variations observed on computed tomography angiography of donor-patient were assessed. Hepatitis serology, hypertension, and cardiovascular disease were determined. Mortality and graft loss were also identified.

The presented study was conducted according to the declaration of Helsinki and the Istanbul Okan University, Ethical Board approved the study protocol (March 13 ${ }^{\text {th }} 2019,104$ ).

\section{Statistical Analysis}

NCSS (Number Cruncher Statistical System) 2007 (Kaysville, Utah, USA) program was used for statistical analysis. Descriptive statistical methods (mean, standard deviation, median, first quadrant, third quadrant, frequency, percentage, minimum, maximum) were used when study data were evaluated.

\section{Results}

Mean age of donor patients was 44.05 \pm 13.76 (18-71) years. Mean hospitalization time of donor patients were $3.56 \pm 1.32$ (2-6) days. Preoperative mean creatinine was $0.78 \pm 0.11 \mathrm{mg} /$ dl (0.58-1.18) and mean creatinine was $1.04 \pm 0.25$ (0.731.83) $\mathrm{mg} / \mathrm{dl}$ six months after donor nephrectomy (Table 1 ).

All living donors had computed tomography angiography for assessment of the vascular structure of both kidneys. Accessory right kidney artery was the most dominant vascular variation (16.5\%) (Table 2 ).

Ninety-four (94\%) were the first, five (5\%) were the second, and one (1\%) was the third transplants. Mean age of recipients was $43.4 \pm 12.93$ (13-65). The cause of primary renal failure is unknown. The primary cause of the chronic renal disease was diabetes mellitus (5\%) and hypertension (15\%).

Table 1. Demographic features and creatinine levels of donor patients Mean \pm SD (Min-Max)

\begin{tabular}{|c|c|}
\hline \multicolumn{2}{|l|}{ Age (years) } \\
\hline Male $(n=47)$ & $40.2 \pm 13.64(18-70)$ \\
\hline Female $(n=48)$ & $47.71 \pm 13.13(18-71)$ \\
\hline \multicolumn{2}{|l|}{ Height $(\mathrm{cm})$} \\
\hline Male $(n=47)$ & $170.88 \pm 8.35$ (147-188) \\
\hline Female $(n=48)$ & $162.38 \pm 7.27(141-180)$ \\
\hline \multicolumn{2}{|l|}{ Weight (kg) } \\
\hline Male $(n=47)$ & $63.0 \pm 2.64(49-103)$ \\
\hline Female $(n=48)$ & $73.99 \pm 12.1(47-107)$ \\
\hline \multicolumn{2}{|l|}{ BMI (kg/m2) } \\
\hline Male $(n=47)$ & $27.12 \pm 4.53(19.7-40.3)$ \\
\hline Female $(n=48)$ & $28.94 \pm 5.50(18.6-40.1)$ \\
\hline Hospitalization time (days) & $3.56 \pm 1.32(2-6)$ \\
\hline $\begin{array}{l}\text { Preoperative creatinine } \\
(\mathrm{mg} / \mathrm{dl})(\mathrm{n}=95)\end{array}$ & $0.78 \pm 0.11(0.58-1.18)$ \\
\hline $\begin{array}{l}\text { Postoperative day } 1 \text { creatinine } \\
(\mathrm{mg} / \mathrm{dl})(\mathrm{n}=95)\end{array}$ & $1.02 \pm 0.30(0.54-1.69)$ \\
\hline $\begin{array}{l}\text { Postoperative day } 7 \text { creatinine } \\
(\mathrm{mg} / \mathrm{dl})(\mathrm{n}=95)\end{array}$ & $1.19 \pm 0.26(0.75-1.97)$ \\
\hline $\begin{array}{l}\text { Postoperative day } 30 \text { creatinine } \\
(\mathrm{mg} / \mathrm{dl})(\mathrm{n}=95)\end{array}$ & $1.16 \pm 0.28(0.75-1.97)$ \\
\hline $\begin{array}{l}\text { Postoperative day } 180 \text { creatinine } \\
(\mathrm{mg} / \mathrm{dl})(\mathrm{n}=46)\end{array}$ & $1.04 \pm 0.25(0.73-1.83)$ \\
\hline
\end{tabular}

Table 2. Computed tomography angiography features of arteries in donor patients

\begin{tabular}{lcc}
\hline & Female (n=48, \%) & Male $(\mathbf{n = 4 7 , ~ \% ) ~}$ \\
\hline Single left RA* & $39(84.8)$ & $32(71.1)$ \\
Single right RA* & $38(82.6)$ & $32(71.1)$ \\
Accessory right RA* & $6(13)$ & $9(20)$ \\
Accessory left RA* & $5(10.8)$ & $9(20)$ \\
Accessory left-right RA* & $2(4.3)$ & $4(8.9)$ \\
Polar left RA* & & $1(2.2)$ \\
Polar right RA* & $1(2.2)$ & $2(4.4)$ \\
Polar left-right RA* & & $1(2.2)$ \\
\hline
\end{tabular}

*RA: Renal artery. 
Fifty patients were preemptive. Primary initial replacement therapy was hemodialysis in 43 (43\%) patients. Mean hospitalization time of recipient patients were $9.21 \pm 4.91$ (4-32) days. Preoperative mean creatinine was $6.76 \pm 2.85 \mathrm{mg} / \mathrm{dl}$ (4.55-11.69) and mean creatinine was $2.46 \pm 0.23$ (0.77-8.33) $\mathrm{mg} / \mathrm{dl}$ six months after transplantation (Table 3) (Fig. 1).

Seventy-four (77.8\%) left, twenty-one (22.2\%) right donor nephrectomies were performed, and seven of them

Table 3. Demographic features, comorbid conditions and creatinine levels of recipients

\begin{tabular}{|c|c|c|}
\hline & n (\%) & Mean \pm SD (Min-Max) \\
\hline Age (years) & $100(100)$ & $43.4 \pm 12.93(13-65)$ \\
\hline Height (cm) & $100(100)$ & $168.6 \pm 9.58(141-189)$ \\
\hline Weight (kg) & $100(100)$ & $69.57 \pm 16.47(31-104)$ \\
\hline $\mathrm{BMI}^{*}\left(\mathrm{~kg} / \mathrm{m}^{2}\right)$ & $100(100)$ & $24.4 \pm 3.36(19.4-40.1)$ \\
\hline $\begin{array}{l}\text { Family History of chronic } \\
\text { kidney disease }\end{array}$ & $13(13)$ & \\
\hline Smoker & $21(21)$ & \\
\hline Ex-smoker & $6(6)$ & \\
\hline Hospitalization time (days) & $100(100)$ & $9.21 \pm 4.91(4-32)$ \\
\hline Comorbid conditions & & \\
\hline Diabetes mellitus & $35(35)$ & \\
\hline Diabetes mellitus+hypertension & $7(7)$ & \\
\hline $\begin{array}{l}\text { Diabetes mellitus+ } \\
\text { hypertension+ coronary artery }\end{array}$ & $9(9)$ & \\
\hline disease & $15(15)$ & \\
\hline Hypertension & & \\
\hline $\begin{array}{l}\text { Hypertension+ coronary } \\
\text { artery disease }\end{array}$ & $5(5)$ & \\
\hline $\begin{array}{l}\text { Coronary artery disease+ } \\
\text { peripheral vascular disease }\end{array}$ & $2(2)$ & \\
\hline Amyloidosis & $4(4)$ & \\
\hline Goodpasture's syndrome & $2(2)$ & \\
\hline Nephrolithiasis & $8(8)$ & \\
\hline $\begin{array}{l}\text { Focal segmental } \\
\text { glomerulosclerosis }\end{array}$ & $2(2)$ & \\
\hline Systemic lupus erythematosus & $1(1)$ & \\
\hline Polycystic kidney disease & $1(1)$ & \\
\hline Preoperative creatinine (mg/dl) & $100(100)$ & $6.76 \pm 2.85(4.55-11.69)$ \\
\hline $\begin{array}{l}\text { Postoperative day } 1 \\
\text { creatinine (mg/dl) }\end{array}$ & $100(100)$ & $3.15 \pm 1.72(0.84-9.67)$ \\
\hline $\begin{array}{l}\text { Postoperative day } 7 \\
\text { creatinine (mg/dl) }\end{array}$ & $100(100)$ & $1.8 \pm 1.64(0.65-7.94)$ \\
\hline $\begin{array}{l}\text { Postoperative day } 30 \\
\text { creatinine (mg/dl) }\end{array}$ & $100(100)$ & $1.76 \pm 1.61(0.6-6.56)$ \\
\hline $\begin{array}{l}\text { Postoperative day } 180 \\
\text { creatinine }(\mathrm{mg} / \mathrm{dl})\end{array}$ & $49(49)$ & $2.46 \pm 0.23(0.77-8.33)$ \\
\hline Previous hemodialysis (months) & $46(46)$ & $18.3 \pm 22.3(1-60)$ \\
\hline Previous CAPD** (months) & $3(3)$ & $4.24 \pm 4(1-7)$ \\
\hline Previous blood transfusion (units) & $16(16)$ & $3.23 \pm 2.12(1-15)$ \\
\hline
\end{tabular}

*BMI: Body mass index; ${ }^{*}$ CAPD: Continuous ambulatory peritoneal dialysis.
(7.36\%) were converted from the laparoscopic approach to open approach. In all cases converted to open procedure, the cause was uncontrolled bleeding. Mean warm and cold ischemia time was $1.82 \pm 0.44(1-3)$ and $40.25 \pm 6.12$ (31-57) minutes, respectively. Double-J ureteral catheter was placed in 80 patients and mean removal time of the catheter was 27.2 $\pm 20.1(11-126)$ days. The most observed postoperative complication was stenosis of ureter anastomosis (4\%). End-to-end arterial anastomosis between renal and internal iliac arteries is the most preferred anastomosis (58\%) (Table 4). One graft (1\%) was loft due to vein anastomosis dehiscence.

Table 4. Surgical features and observed surgical complications of recipient patients

\begin{tabular}{|c|c|c|}
\hline & n (\%) & $\begin{array}{l}\text { Mean } \pm S D \\
\text { (Min-Max) }\end{array}$ \\
\hline Transplantation from living donor & $95(95)$ & \\
\hline Transplantation from a cadaveric donor & $5(5)$ & \\
\hline Warm ischemia time (minute) $(\mathrm{n}=91)$ & & $1.82 \pm 0.44(1-3)$ \\
\hline Cold ischemia time (minute) $(n=91)$ & & $40.25 \pm 6.12(31-57)$ \\
\hline Double J catheter removal (day) $(n=80)$ & & $27.2 \pm 20.1(11-126)$ \\
\hline \multicolumn{3}{|l|}{ Postoperative complications } \\
\hline Arterial anastomosis dehiscence & $1(1)$ & \\
\hline Ureter anastomosis leakage & $1(1)$ & \\
\hline Stenosis of ureter anastomosis & $4(4)$ & \\
\hline Renal arterial stenosis & $1(1)$ & \\
\hline Pulmonary embolism & $1(1)$ & \\
\hline Severe seroma o the surgical side & $1(1)$ & \\
\hline Hematoma o the surgical side & $1(1)$ & \\
\hline \multicolumn{3}{|l|}{ Arterial anastomosis } \\
\hline $\begin{array}{l}\text { End-to-side (renal artery to external } \\
\text { iliac artery) }\end{array}$ & $42(42)$ & \\
\hline $\begin{array}{l}\text { End-to-end (renal artery to internal } \\
\text { iliac artery) }\end{array}$ & $58(58)$ & \\
\hline Anastomosis to vascular graft & $1(1)$ & \\
\hline
\end{tabular}

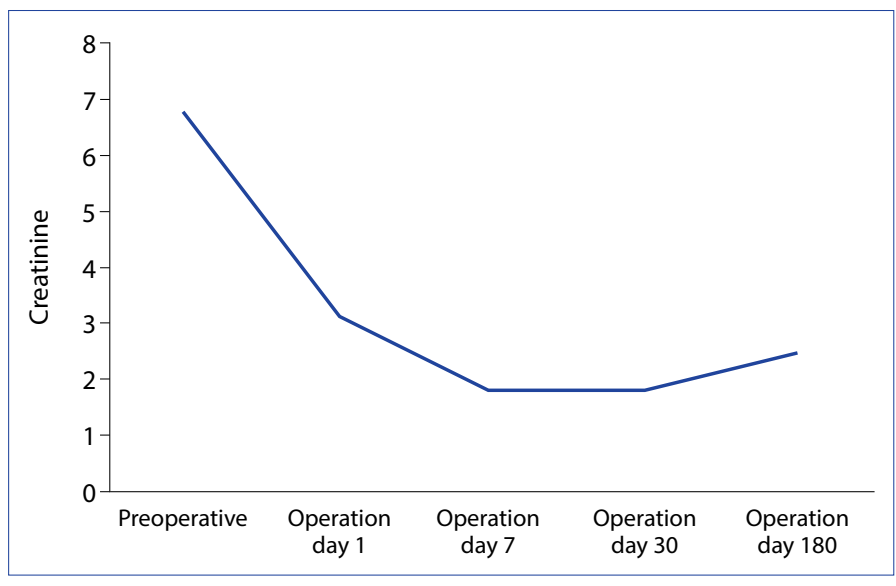

Figure 1. Mean creatinine change of recipient over a six-month period. 


\section{Discussion}

The first kidney transplant was performed in the world in 1954, while it was first performed in our country in 1975. Since 1975, the number of kidney transplant patients and transplant centers operating in Turkey has increased every year (Fig. 2), and the number of patients suffering from end-stage renal disease also increased. ${ }^{[4]}$ In 2018, 76 of 99 organ transplantation centers performed kidney transplantation, 3011 living donors and 859 cadaveric donor kidney transplantations were performed. ${ }^{[7]}$

There is no upper age limit for excluding patient from kidney transplantation. However, the age limit for kidney transplantation, which is generally accepted, ranges between 5-60 years of age and the best result is reported to be between $10-50$ years of age. ${ }^{[8]}$ Batabyal et al. ${ }^{[9]}$ published a systematic review, including fifteen guidelines on kidney transplantation. Majority of guidelines stated that age is not an ineligibility criterion for kidney transplantation. The UK Renal Association guidelines recommended that "age is not a contraindication to transplantation".[10] The American Society of Transplantation guidelines also pointed out that "there should be no absolute upper age limit for excluding patients whose overall health and life situation suggest that transplantation will be beneficial"..11] In the presented study, the mean age of recipient patients was $43.4 \pm 12.93$ years and, while the oldest patient was 65 years old, the youngest one was thirteen. Many studies have revealed that kidney transplantation is a safe surgical procedure with a better survival rate compared to hemodialysis for elderly end-stage kidney failure patients. ${ }^{[12-14]}$ However, many transplant centers and surgeons are still hesitant to operate elderly patients for kidney transplantation. We think this hesitancy is due to prejudiced opinions because there are no defined absolute criteria for elderly patients.

Accessory arteries of the kidney are the most prevalent and clinically significant vascular variation of kidneys. ${ }^{[15]}$ Incompatible with the literature, accessory arteries are the most observed variation of donor kidneys. ${ }^{[15-17]}$ The knowledge

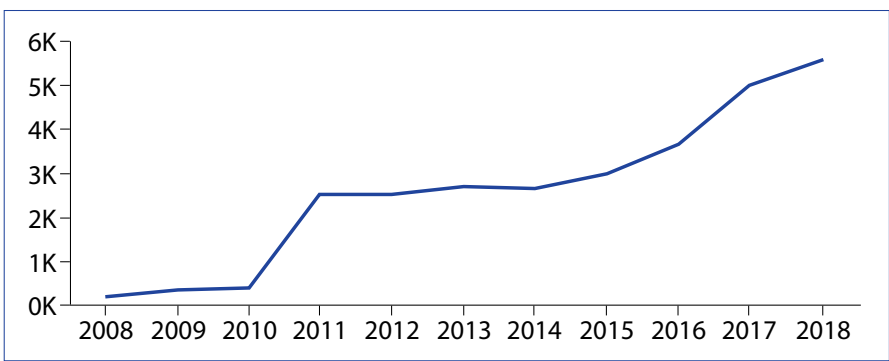

Figure 2. The increase of kidney transplants in Turkey over a 10-year period (Data obtained from the website of the Turkish Ministry of Health). of these vascular variations of the kidney is essential for surgeons performing kidney transplantation. Thus, evaluation of these vascular variations before transplant surgery is necessary for operative planning. Computed tomography angiography provides useful information about vascular alterations of the kidney.

Most observed complications of kidney transplant surgery involve renal artery, renal vein, or ureter anastomoses and most of these complications require surgical or radiologic intervention for proper treatment (Table 5). ${ }^{[18-20]}$ Our most observed complication was stenosis of ureteroneocystostomy, and three of four complicated cases were treated by a second surgical approach, the interventional radiological approach solved one case. Despite these improvements in outcomes, instances of graft-threatening ureteral obstruction still occur. ${ }^{[21,22]}$ Early stenosis is most often related to perioperative factors, such as a narrow ureterovesical anastomosis, ureteral kinking, or external compression by a lymphocele or hematoma. ${ }^{[23]}$ Late stenosis generally occurs due to fibrosis of anastomotic side from chronic ischemia, and polyomavirus BK virus is a known reason for ureter stenosis, reporting a prevalence of 2 to $6 \% \cdot{ }^{[24-28]}$ Elevated serum creatinine level, which should be discriminated from other causes, alerts the surgeon (Table 6). Ultrasonographic evaluation of the graft usually demonstrates hydronephrosis, which is a useful screening tool, yet the most specific diagnostic method is the percutaneous nephrostogram. Percutaneous balloon dilatation of the obstructed anastomosis by interventional radiology and stent placement may yield good results. ${ }^{[18]}$ However, in case of failure, the surgical approach should be preferred. $[19,20]$ Reanastomosis of neoureter for distal strictures or anastomosis of neoureter to native urether may be used to bypass the obstruction side. The most severe observed complication in this series was dehiscence of end-to-side arterial anastomosis between the renal artery and external iliac artery, which was solved by creating a new endto-side arterial anastomosis via a PTFE vascular graft. The most common cause of vascular anastomosis dehiscence is pseudoaneurysm and hypertension, tissue trauma, weakness of a branch, weakness around valves secondary to absence of circular muscle in the media, atherosclerotic changes, mycotic vasculitis, and dissection of the vein graft is associated risk factors for pseudoaneurysm formation. [29] Comorbid conditions of hypertension, coronary artery disease, and surgical trauma were associated risk factors of our case.

Although some doubts sustain on what the best method for kidney artery anastomosis is: end-to-side or end-to-end? Since the use of large Carrel patch obtained from abdominal aorta, creating an end-to-side anastomosis between re- 


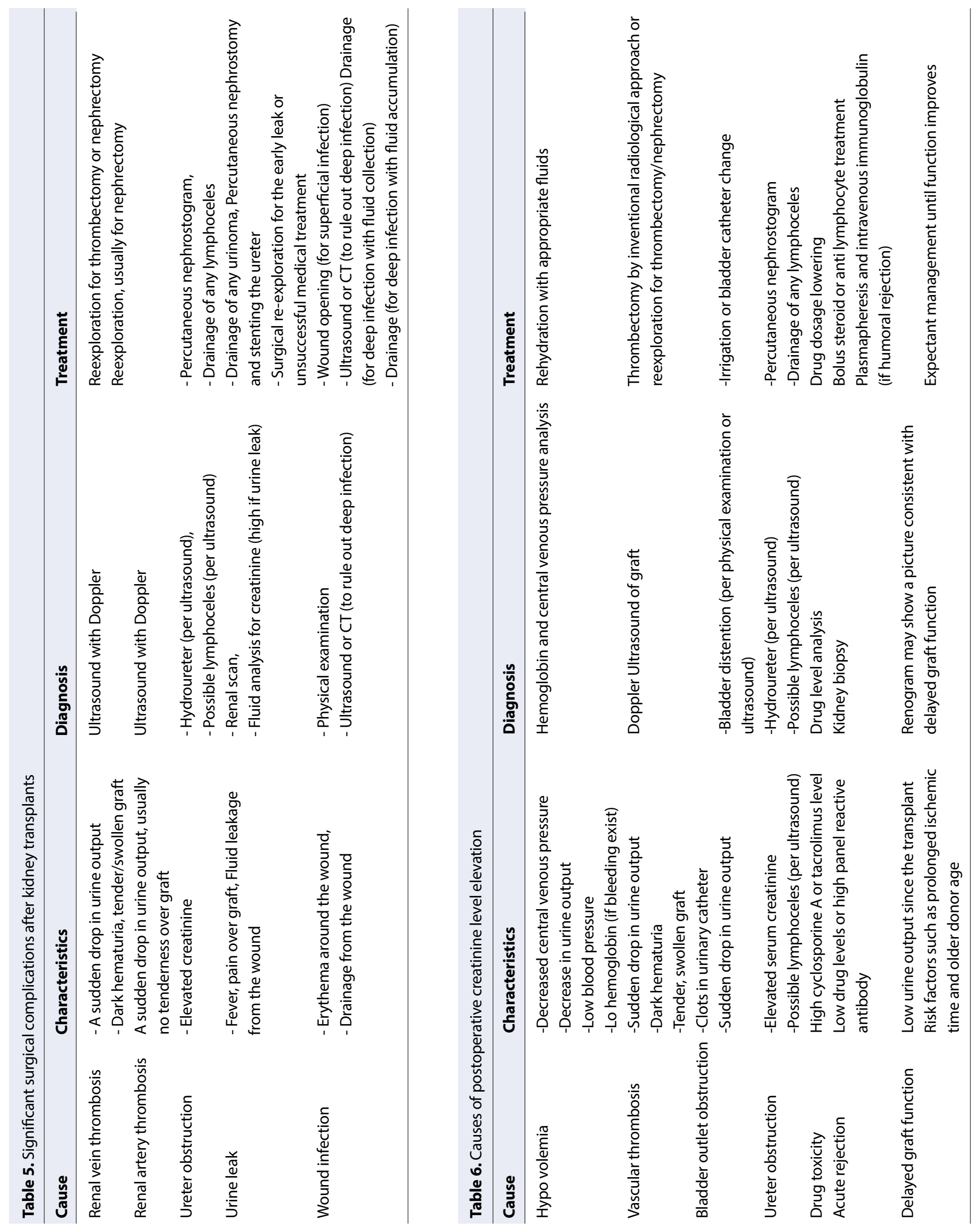


nal artery and the external iliac artery is the preferred surgical method in transplantation from deceased donor, ${ }^{[30]}$ and if a kidney from a living donor is transplanted, the typical choice is the end-to-end anastomosis between the kidney artery and internal iliac artery at many centers. ${ }^{[30,31]}$ In the presented study, the dominant anastomosis technique is end-to-end anastomosis to internal iliac artery if mobilization of the artery and the length of the transplanted artery are sufficient. We prefer this anastomosis technique so that interventional radiology can interfere more efficiently with a future complication. However, no well-designed prospective studies comparing the results of these two methods are available with long-term follow-up.

\section{Conclusion}

The number of kidney transplants performed in Turkey is continuously increasing over the years, but considering the number of dialysis-dependent patients in our country, we think that the number of transplantations is still far below the number of transplantations needed. The most critical negative issue for our country potential is the cadaveric donation rate is lower than expected. Increasing kidney transplantation, which is the most appropriate treatment in terms of cost-effectiveness, will be beneficial for patient health and economy of the country.

\section{Disclosures}

Ethics Committee Approval: The presented study was conducted according to the declaration of Helsinki and the Istanbul Okan University, Ethical Board approved the study protocol (March 13th 2019,104).

Peer-review: Externally peer-reviewed.

Conflict of Interest: None declared.

Authorship Contributions: Concept - M.F.F.; Design - M.F.F.; Supervision - A.G.; Materials - T.K., Ac.K., A.I.F.; Data collection \&/or processing - M.F.F.; Analysis and/or interpretation - M.F.F., A.G.; Literature search - Ac.K.; Writing - M.F.F.; Critical review - A.K.

\section{References}

1. Kute VB, Prasad N, Shah PR, Modi PR. Kidney exchange transplantation current status, an update and future perspectives. World J Transplant 2018;8:52-60. [CrossRef]

2. Purnell TS, Luo X, Cooper LA, Massie AB, Kucirka LM, Henderson $\mathrm{ML}$, et al. Association of Race and Ethnicity With Live Donor Kidney Transplantation in the United States From 1995 to 2014. JAMA 2018;319:49-61. [CrossRef]

3. Waterman AD, Morgievich M, Cohen DJ, Butt Z, Chakkera HA, Lindower $C$, et al. Living Donor Kidney Transplantation: Improving Education Outside of Transplant Centers about Live Donor Transplantation-Recommendations from a Consensus Conference. Clin J Am Soc Nephrol 2015;10:1659-69. [CrossRef]
4. Sagıroglu T, Yıldırım M, Meydan B, Cobanoglu M. Retrospective analysis of kidney transplanted patients. Dicle Tıp Dergisi 2009:36;75-9.

5. Global observatory on donation and transplantation. Available at: http://www.transplant-observatory.org/countkidney/. Accessed Feb 10, 2019.

6. Cantwell L, Woodroffe C, Holdsworth R, Ferrari P. Four years of experience with the Australian kidney paired donation programme. Nephrology (Carlton) 2015;20:124-31. [CrossRef]

7. Turkish Ministry of Health, Organ, Tissue Transplantation and Dialysis Services Department Official Page (Feb 10, 2019).

8. Veroux M, Grosso G, Corona D, Mistretta A, Giaquinta A, Giuffrida $G$, et al. Age is an important predictor of kidney transplantation outcome. Nephrol Dial Transplant 2012;27:1663-71. [CrossRef]

9. Batabyal P, Chapman JR, Wong G, Craig JC, Tong A. Clinical practice guidelines on wait-listing for kidney transplantation: consistent and equitable? Transplantation 2012;94:703-13. [CrossRef]

10. Dudley C, Harden P. Renal Association Clinical Practice Guideline on the assessment of the potential kidney transplant recipient. Nephron Clin Pract 2011;118 Suppl 1:c209-24. [CrossRef]

11. Kasiske BL, Cangro CB, Hariharan S, Hricik DE, Kerman RH, Roth $D$, et al; American Society of Transplantation. The evaluation of renal transplantation candidates: clinical practice guidelines. Am J Transplant 2001;1 Suppl 2:3-95. [CrossRef]

12. Hod T, Goldfarb-Rumyantzev AS. Clinical issues in renal transplantation in the elderly. Clin Transplant 2015;29:167-75. [CrossRef]

13. Ponticelli $C$, Podestà MA, Graziani G. Renal transplantation in elderly patients. How to select the candidates to the waiting list? Transplant Rev (Orlando) 2014;28:188-92. [CrossRef]

14. Segall L, Nistor I, Pascual J, Mucsi I, Guirado L, Higgins R, et al. Criteria for and Appropriateness of Renal Transplantation in Elderly Patients With End-Stage Renal Disease: A Literature Review and Position Statement on Behalf of the European Renal AssociationEuropean Dialysis and Transplant Association Descartes Working Group and European Renal Best Practice. Transplantation 2016;100:e55-65. [CrossRef]

15. Khamanarong K, Prachaney P, Utraravichien A, Tong-Un T, Sripaoraya K. Anatomy of renal arterial supply. Clin Anat 2004;17:334-6.

16. Ciçekcibaşi $A E$, Ziylan $T$, Salbacak $A$, Seker $M$, Büyükmumcu $M$, Tuncer I. An investigation of the origin, location and variations of the renal arteries in human fetuses and their clinical relevance. Ann Anat 2005; 187:421-7. [CrossRef]

17. Satyapal KS, Haffejee AA, Singh B, Ramsaroop L, Robbs JV, Kalideen JM. Additional renal arteries: incidence and morphometry. Surg Radiol Anat 2001;23:33-8. [CrossRef]

18. Kristo B, Phelan MW, Gritsch HA, Schulam PG. Treatment of renal transplant ureterovesical anastomotic strictures using antegrade balloon dilation with or without holmium:YAG laser endoureterotomy. Urology 2003;62:831-4. [CrossRef]

19. Rosenthal JT. Surgical management of urological complications after kidney transplantation. Semin Urol 1994;12:114-22. 
20. Humar A, Matas AJ. Surgical complications after kidney transplantation. Semin Dial 2005;18:505-10. [CrossRef]

21. Beyga ZT, Kahan BD. Surgical complications of kidney transplantation. J Nephrol 1998;11:137-45.

22. Streeter EH, Little DM, Cranston DW, Morris PJ. The urological complications of renal transplantation: a series of 1535 patients. BJU Int 2002;90:627-34.

23. Kumar S, Jeon JH, Hakim A, Shrivastava S, Banerjee D, Patel U. Long-term Graft and Patient Survival after Balloon Dilation of Ureteric Stenosis after Renal Transplant: A 23-year Retrospective Matched Cohort Study. Radiology 2016;281:301-10. [CrossRef]

24. Geddes CC, Gunson R, Mazonakis E, Wan R, Thomson L, Clancy M, et al. BK viremia surveillance after kidney transplant: single-center experience during a change from cyclosporine-to lower-dose tacrolimus-based primary immunosuppression regimen. Transpl Infect Dis 2011;13:109-16. [CrossRef]

25. Coleman DV, Mackenzie EF, Gardner SD, Poulding JM, Amer B, Russell WJ. Human polyomavirus (BK) infection and ureteric stenosis in renal allograft recipients. J Clin Pathol 1978;31:338-47.
26. Mackenzie EF, Poulding JM, Harrison PR, Amer B. Human polyoma virus (HPV)--a significant pathogen in renal transplantation. Proc Eur Dial Transplant Assoc 1978;15:352-60.

27. Gardner SD, MacKenzie EF, Smith C, Porter AA. Prospective study of the human polyomaviruses $\mathrm{BK}$ and $\mathrm{JC}$ and cytomegalovirus in renal transplant recipients. J Clin Pathol 1984;37:578-86. [CrossRef]

28. van Aalderen MC, Heutinck KM, Huisman C, ten Berge IJ. BK virus infection in transplant recipients: clinical manifestations, treatmentoptions and the immune response. Neth J Med 2012;70:172-83.

29. Mohara J, Konishi H, Kato M, Misawa Y, Kamisawa O, Fuse K. Saphenous vein graft pseudoaneurysm rupture after coronary artery bypass grafting. Ann Thorac Surg 1998;65:831-2. [CrossRef]

30. Matheus WE, Reis LO, Ferreira U, Mazzali M, Denardi F, Leitao VA, et al. Kidney transplant anastomosis: internal or external iliac artery? Urol J 2009;6:260-6.

31. Ersöz S, Anadol E, Aydintuğ S, Bumin C, Erkek B, Ateş K. Anastomotic artery stenosis in living related kidney transplantation: the impact of anastomotic technique. Transplant Proc 1996;28:2331-2. 